Volume 6 No 2 Maret 2021

p-ISSN: 2460-8750 e-ISSN: 2615-1731

https://doi.org/10.26858/talenta.v6i2.19891

\title{
Efektivitas Modifikasi Perilaku Melalui Teknik Token Ekonomi Untuk Menurunkan Perilaku Conduct Disorder pada Remaja Putri
}

\author{
Dini Rakhmawati, H. Fuad Nashori' ${ }^{1}$, Qurotul Uyun \\ Program Studi Psikologi Profesi (S2), Fakultas Psikologi dan Ilmu Sosial Budaya, \\ Universitas Islam Indonesia, Yogyakarta \\ ${ }^{1}$ Email: fuadnashori@uii.ac.id
}

(C2018 -JPT Fakultas Psikologi Universitas Negeri Makassar. Ini adalah artikel dengan

akses terbuka di bawah licenci CC BY-NC-4.0 (https://creativecommons.org/licenses/by-nc/4.0/ ).

\begin{abstract}
There is a lot of research about the Conduct Disorders in male subjects, but research on the Conduct Disorders in female subjects relatively minimal. The purpose of this study is to reveal the effectiveness of behavior modification to reduce Conduct Disorders behaviour in adolescent girls using token economy techniques. Research conducted on a teenager who suffered Conduct Disorders antisocial types, female, 16 years old, had no formal education, have a level of intelligence below the average. With single-subject research design with ABA-type single-factor baseline, the reduction behavior seen from a comparison between the results of the test before and after the intervention. The results showed a decrease in the aspect of aggressive behavior (14 points), attention problems (11 points), deliquent behavior (10 points), withdrawn (10 points), social problems (5 points), anxiety/depression (4 points), thought problems (1 point), and somatic complaints $(0$ points). Thus the behavior modification using token economy technique effective to decrease the Conduct Disorders in adolescent girls.
\end{abstract}

Keywords: Conduct Disorders, Token Economy, Young Women

\begin{abstract}
ABSTRAK
Ada banyak penelitan mengenai Conduct Disorder pada jenis kelamin lelaki, namun penelitian mengenai Conduct Disorder pada subjek berjenis kelamin perempuan tergolong minim. Tujuan penelitian ini adalah untuk mengungkapkan efektivitas modifikasi perilaku dengan teknik token ekonomi untuk menurunkan perilaku Conduct Disorders pada remaja putri. Penelitian dilakukan terhadap seorang remaja yang mengalami Conduct Disorders tipe antisosial, berjenis kelamin perempuan, berusia 16 tahun, tidak memiliki pendidikan formal, memiliki tingkat kecerdasan dibawah rata-rata. Dengan desain penelitian single-subject dengan tipe ABA Single-factor baseline, penurunan perilaku dilihat dari perbandingan antara hasil tes sebelum dan setelah intervensi. Hasil penelitian menunjukkan terjadi penurunan pada aspek Perilaku agresif (14 poin), masalah perhatian (11 poin), perilaku melawan (10 poin), perilaku menarik diri (10 poin), masalah sosial (5 poin), kecemasan/depresi (4 poin), masalah pikiran (1 poin), dan keluhan somatik (0 poin). Dengan demikian modifikasi perilaku dengan teknik token ekonomi efektif untuk menurunkan perilaku Conduct Disorder pada remaja putri.
\end{abstract}

Kata Kunci: Conduct Disorders, Token Ekonomi, Remaja Putri 


\section{PENDAHULUAN}

Sebagai generasi penerus bangsa, anak-anak selayaknya dirawat, dididik, dan diperlakukan dengan baik. Negara menjamin keberadaan anak dan melindungi hak-haknya melalui Undang-undang RI Nomor 35 tahun 2014 tentang perlindungan anak (kpai.go.id, tanggal unduh 10 Februari 2021). Di dalam undang-undang perlindungan anak tersebut dicantumkan hak anak untuk mendapatkan perlindungan dari tindakan kekerasan. Dari undang-undang yang sudah ada, seharusnya anak mendapatkan perlindungan yang sudah dijamin oleh negara. Namun, pada kenyataannya banyak kasus yang ditemukan bahwa anak menjadi korban kekerasan seksual.

Kasus kekerasan seksual terhadap anak merupakan salah satu jenis kasus yang mengalami peningkatan secara signifikan belakangan ini. Survey nasional mengenai kekerasan terhadap anak yang dilaksanakan pada tahun 2018 oleh Kementerian PPPA, menemukan bahwa 62 persen anak perempuan dan laik-laki mengalami saru atau lebih dari satu bentuk kekerasan sepanjang hidupnya. Survei itu juga menemukan bahwa satu dari 11 anak perempuan dan satu dari 17 anak laki-laki mengalami kekerasan seksual (Unicef, 2020)

Selaras dengan data Unicef, Kementerian Pemberdayaan Perempuan dan Anak (Kemen PPPA) sejak 31 juli 2020 tercatat ada 4.116 kasus kekerasan pada anak. Dari angka tersebut yang paling tinggi adalah angka korban kekerasan seksual, yakni 2.556 kasus. Dari 2.556 kasus kekerasan seksual tersebut, 1.111 adalah korban kekerasan seksual secara fisik, sedangkan 979 kasus adalah korban kekerasan psikis (nasional.kompas.com, 2021).

Kekerasan seksual menimbulkan banyak efek negatif pada diri seorang anak, baik secara fisik maupun psikologis. Menurut Katona, Cooper dan Robertson (2012), anak korban kekerasan seksual cenderung mengalami gangguan emosi, tingkah laku, depresi, gangguan kepribadian dan gangguan konversi. Temuan Katona dkk diperkuat oleh hasil temuan Noviana (2015) di mana anak yang menjadi korban kekerasan seksual akan mengalami dampak psikologis berupa pengkhianatan atau hilangnya kepercayaan anak terhadap orang dewasa, trauma secara seksual, merasa tidak berdaya dan stigma. Lebih mendalam lagi, Rossa, Reinholz dan Angelini (Maslihah, 2013) menyatakan bahwa anak yang pernah mengalami kekerasan seksual akan mengalami perasaan bersalah dan menyalahkan diri sendiri, bayangan kejadian di mana anak menerima kekerasan seksual, mimpi buruk, insomnia, takut hal yang berhubungan dengan penyalahgunaan (termasuk benda, bau, tempat, kunjungan dokter, dan lain-lain), masalah harga diri, disfungsi seksual, sakit kronis, kecanduan, keinginan bunuh diri cedera, bunuh diri, keluhan somatik, serta depresi. Dari hasil temuan beberapa ahli, dapat disimpulkan bahwa pelecehan seksual mampu menimbulkan permasalahan jangka pendek dan jangka panjang pada seorang anak. Dampak fisik terburuk yang memungkinkan untuk terjadi pada anak korban kekerasan seksual dapat ditemukan pada kasus kematian anak berinisial ZN. Pada kasus anak ZN korban meninggal setelah koma selama dua pekan akibat tindakan pelecehan seksual (www.merdeka.com, 2021). Adapun dampak psikologis dari kekerasan seksual pada anak bisa berlangsung dalam jangka panjang maupun jangka pendek jika tidak ditangani dengan benar.

Ada banyak cara yang bisa dilakukan untuk mengatasi efek samping kekerasan seksual pada anak. Salah satunya dilakukan oleh negara melalui Dinas Sosial. Dinas Sosial memiliki UPT (Unit Pelayanan Tugas) yang menangani anak-anak dengan permasalahan pelanggaran hak secara undang-undang. Di Yogyakarta sendiri, UPT yang menangani hal tersebut ada di Panti Sosial Asuhan Anak (PSAA), terdiri atas dua panti sosial, salah satunya adalah PSAA Bimomartani. PSAA Bimomartani merawat puluhan orang anak. Anak-anak yang berada di dalam PSAA Bimomartani berasal dari berbagai lokasi di kota Yogkakarta dan berada dalam pengasuhan dinas sosial karena berbagai sebab. Adapun alasan yang 
membuat seorang anak berada dalam pengasuhan PSAA Bimo antara lain anak yatim, anak piatu, anak yatim piatu, anak terlantar, anak dari keluarga miskin, anak korban kekerasan dan lain-lain. Salah satu anak yang berada dalam pengasuhan PSAA Bimo merupakan korban dari kekerasan seksual yang dilakukan oleh tetangganya. Dari skrining awal menggunakan Children Behavioural Checklist, diketahui bahwa subjek menunjukkan gangguan perilaku.

Gangguan perilaku (conduct disorder) adalah diagnosis psikiatri yang ditandai dengan pola perilaku berulang dan terus-menerus melanggar hak-hak dasar orang lain, norma atau aturan social baku yang sesuai usia (Pisano dkk, 2017). Adapun Lillig (2018) menyatakan bahwa conduct disorder adalah gangguan perilaku yang paling sering terjadi pada masa kanak-kanak dan remaja. Ditandai dengan gejala agresi terhadap manusia atau hewan, perusakan benda-benda, berbohong dan pelanggaran serius terhadap aturan. Penderita conduct disorder biasanya memperlihatkan perilaku menggangu, melanggar aturan, mulai dari yang yang terkecil seperti merengek, menyumpah atau marah sampai ke pelanggaran dalam bentuk yang lebih serius seperti vandalisme, pencurian dan penyerangan (Mash, 2013). Lillig (2018) lebih memerinci perilaku yang mudah ditemukan pada penderita conduct disorder antara lain mencuri, melarikan diri, membakar, membolos, menghancurkan, kejam kepada hewan maupun orang, memaksakan tindakan seksual, menipu atau mengambil keuntungan dari orang lain dengan cara menipu, mengancam secara fisik maupun psikis, melawan orang tua, melanggar aturan dan lain sebagainya.

Mash (2013) menyatakan bahwa anak-anak dengan masalah gangguan perilaku sebagian besar berasal dari lingkungan keluarga yang penuh kekerasan fisik, mengalami penelantaran dan kemiskinan. Perilaku anti sosial muncul namun menurun selama masa perkembangan. Kebanyakan balita memukul, menendang, sengaja merusak barang, berbohong, dan menolak otoritas orang dewasa, tetapi sebagian juga belajar untuk mengendalikan perilaku ini pada saat mereka masuk sekolah. Archenback (Rider dkk, 2019) mengungkapkan bahwa sekitar 50\% dari orang tua melaporkan bahwa anak-anak prasekolah mereka mencuri, berbohong, tidak taat, atau menghancurkan properti. Ini berbeda dengan remaja di mana hanya $10 \%$ dari orang tua yang melaporkan hal yang sama tentang remaja. Penurunan ini mencerminkan kurangnya kesadaran orang tua atas masalah remaja yang mereka hadapi. Meskipun banyak gangguan perilaku berkurang dengan usia, anak-anak yang sejak awal memperlihatkan perilaku sangat agresif secara fisik cenderung relative mempertahankan perilaku tersebut hingga dewasa (Frick, 2016)

Di PSAA sendiri, ada banyak bentuk gangguan perilaku yang diperlihatkan oleh anakanak penghuni panti sosial tersebut. Dari hasil wawancara dengan pekerja sosial (peksos) diperoleh informasi bahwa pernah terjadi kebakaran di gudang panti yang dilakukan oleh anak penghuni panti, terjadi pencurian yang dilakukan sesama penghuni panti sehingga bisa dilihat bahwa hampir sebagian besar pintu lemari di dalam panti tidak utuh bekas dibongkar. Selain itu, juga terjadi pemukulan serta ancaman kepada seorang pramsos perempuan oleh penghuni panti remaja laki-laki akibat kesalahpahaman, perobekan baju oleh remaja perempuan terhadap pramsos akibat keinginannya tidak terpenuhi, pemukulan dengan menggunakan tongkat besi ke kepala anak oleh remaja panti, dan sebagainya.

Banyak faktor yang dapat berkontribusi atas munculnya gangguan perilaku. Adapun faktor tersebut antara lain kerusakan otak, faktor keturunan, kekerasan dan pengalaman traumatik. Penelitian yang dilakukan oleh Podgurski (2014) menemukan bahwa pengalaman traumatik anak perempuan mampu memunculkan conduct disorder. Kekerasan seksual, kekerasan lingkungan rumah, kekerasan di sekolah, kehilangan dan menyaksikan kekerasan merupakan pengalaman-pengalaman traumatik yang ditemukan oleh Podguski sebagai penyebab munculnya conduct disorder. 
Anak-anak dengan conduct disorder biasanya memiliki permasalahan lain seperti gangguan mood, kecemasan, PTSD, ADHD, dan sebagainya. Penelitian menunjukkan bahwa anak-anak dengan gangguan perilaku dengan masalah internal biasanya tidak mendapatkan penanganan awal yang komprehensif, sehingga tanpa penanganan maka penderita gangguan perilaku akan terus mempertahankan pola tersebut hingga dewasa dan menimbulkan masalah lain seperti masalah kriminal, penyalagunaan obat-obat terlarang atau ketergantungan, penyakit menular seksual, kehamilan tidak diinginkan, perkelahian, dan lain sebagainya (Frick, 2016). Bentuk gangguan tingkah laku antara anak laki-laki dan perempuan berbeda. Pada anak laki-laki bentuk gangguan perilaku yang muncul biasanya lebih agresif seperti mencuri, berkelahi, merusak, atau masalah disiplin sekolah. Sedangkan bentuk gangguan tingkah laku pada anak perempuan biasanya adalah berbohong, membolos, lari dari rumah, pengunaan obat-obatan, dan pelacuran (Santrock, 2019). Perbedaan bentuk perilaku yang muncul inilah yang membuat diagnosis Conduct disorder lebih banyak ditemukan pada anak laki-laki dibandingkan anak perempuan (Podgurski, 2014).

Jumlah diagnosis pada penderita gangguan perilaku sendiri semakin mengalami peningkatan selama beberapa dekade terakhir meskipun perbaikan dalam teknik identifikasi dan intervensi semakin meningkat (Waddell dkk, 2018). Intervensi anak-anak dengan gangguan perilaku bisa sangat kompleks dan menantang. Intervensi dapat diberikan dalam berbagai pengaturan yang berbeda tergantung pada tingkat keparahan perilaku. Selain itu, tantangan lain adalah sikap anak yang tidak kooperatif, rasa takut dan ketidakpercayaan anak terhadap orang dewasa. Dalam mengembangkan rancangan intervensi yang komprehensif, ada banyak pihak yang harus berkolaborasi seperti keluarga, guru, spesialis medis dan sebagainya (Fairchild dkk, 2019).

Gangguan perilaku yang dialami klien membuat klien bermasalah di dalam panti. Hasil temuan lapangan menunjukkan subjek melakukan pemukulan kepada sesama penghuni panti sampai bibir korban pemukulan robek dan mengeluarkan darah, mengucapkan kata-kata kotor kepada siapapun, meremas dan memiting pramu social (pramsos) jika tidak diikuti kemauannya, dan sebagainya. Adapun hasil observasi tersebut diperkuat oleh hasil wawancara dengan pramsos yang mengasuh klien di mana pramsos kerap mendapat perlakuan tidak menyenangkan seperti tangan yang diplintir, baju yang disobek, dilawan, bahkan pramsos melaporkan bahwa klien pernah berbohong mengadukan kepada pimpinan bahwa pramsos memukul dirinya. Selain itu, penghuni panti lain yakni pekerja social (peksos) yang mengawasi klien menyatakan bahwa klien pernah dilaporkan oleh anak lain bahwa ia mencuri uang dari sesama penghuni panti, pramsos juga menyatakan bahwa klien kerap berkelahi, mengancam dan memaki-maki penghuni lain, terutama teman sekamarnya. Peksos mengakui bahwa perilaku klien sebenarnya harus ditangani dengan tegas, namun hal tersebut menyulitkan karena di sisi lain pramsos juga terbelenggu dengan regulasi pengasuhan yang tidak memperbolehkan hukuman tegas untuk anak asuh.

Sesuai dengan tugas yang diberikan oleh negara kepada Dinas Sosial, PSAA Bimo berkewajiban memberi perawatan yang tepat untuk anak-anak yang berada di bawah pengawasannya. Hal ini dikarenakan keberadaan anak-anak tersebut di PSAA juga dikarenakan permasalahan lain yang terjadi dengan orang tua anak asuh tersebut. Permasalahan muncul saat subjek bertindak agresif kepada anak-anak lain karena tindakan tersebut membuat pengasuhan PSAA menjadi tidak efektif dan membuat lingkaran setan kekerasan pada anak lain. Dari penjelasan di atas, diketahui bahwa subjek membutuhkan penanganan khusus untuk mengatasi Conduct disorder yang dimilikinya.

Salah satu dari terapi yang sudah pernah dilakukan untuk mengatasi Conduct disorder adalah intervensi berbasis keluarga. Intervensi berbasis keluarga untuk menangani CD sudah 
berkembang sejak tahun 1962. Adapun yang paling terkenal adalah family functional therapy (FFT) oleh James Alexander (Scott, 2012). Terapi ini dirancang sekitar 8-12 jam sesi untuk kasus yang ringan sampai sedang dan 26-30 jam sesi untuk kasus yang lebih berat. Terdapat empat fase intervensi. Dua fase pertama adalah fase keterlibatan dan motivasi, pada fase ini terapis meningkatkan persepsi bahwa perubahan bisa dilakukan dan meminimalkan persepsi negatif. Teknik yang digunakan meliputi reframing, di mana atribut positif yang ditingkatkan dan memotivasi untuk mengeluarkan emosi terpendam. Tahap ketiga dari FFT adalah menargetkan perubahan perilaku. Efektivitas FFT tergolong baik. Sudah ada lebih dari 10 studi replikasi menunjukkan keberhasilan penggunaan terapi ini (Scott, 2012). Uji coba yang diterbitkan sampai saat ini menuai hasil positif yakni dengan menurunnya tingkat residivisme menjadi 20\% sampai 30\%. Selain FFT, penanganan Conduct disorder juga bisa dilakukan dengan Multisysmic Therapy (MST). MST merupakan intervensi penanganan Conduct disorder yang melibatkan keluarga dan komunitas. Podgurski dkk (2014) menjelaskan bahwa salah satu intervensi Conduct disorder bisa dilakukan dengan intervensi SNAP (Stop Now and Plan). Intervensi ini merupakan treatment dengan menggunakan pendekatan kognitif perilakuan pada anak perempuan usia 12 tahun dengan perilaku agresif.

Modifikasi perilaku merupakan terapi yang berakar dari eksperimen tentang belajar yang dipublikasikan oleh Ivan Pavlov. Terapi ini efektif untuk mengatasi presenting problem. Terapi ini berprinsip bahwa perilaku bisa diperkuat dan diperlemah tergantung pada lingkungan individu. Perilaku positif bisa muncul jika diberi reward (Positive Reinforcement). Begitu pula sebaliknya perilaku negative bisa dikurangi jika diberi hukuman (punishment). Modifikasi perilaku tergolong efektif untuk menangani kasus dengan pasien yang tidak termotivasi. Terapi perilaku juga sangat lazim membantu orang tua dalam mendapatkan kontrol terhadap anak-anak yang mengalami gangguan perilaku membangkang. Terapi modifikasi perilaku memusatkan perhatian pada tingkah laku yang tampak, penghapusan tingkah laku yang maladaptive, mengajarkan perilaku baru dan mempertahankan perilaku yang diinginkan (Corey, 2016).

Pada kasus subjek sendiri, lingkungan subjek yang berada di dalam panti sosial sebenarnya turut memperkuat Conduct disorder yang dimiliki subjek tetap bertahan. Di dalam panti, perhatian dan fokus pramsos maupun peksos secara otomatis harus terbagi dengan anak-anak asuhan lain, sehingga perhatian dan fokus pramsos menjadi hal yang jarang diperoleh. Atensi dalam bentuk teguran dari pramsos terhadap anak asuh atas perilaku negatif justru memperkuat perilaku tersebut. Sedangkan reward terhadap perilaku positif justru jarang diberikan karena terdapat anggapan bahwa perilaku positif adalah hal yang wajar jika dilakukan. Hal ini sangat disayangkan karena, menurut Rayes dan Kazdin (2008), anak dengan Conduct disorder sangat sensitif terhadap pujian (reward) dan bersikap acuh terhadap hukuman (punishment). Modifikasi perilaku melalui token diharapkan bisa menjadi salah satu cara cepat untuk membantu peksos maupun pramsos untuk menurunkan perilaku Conduct disorder subjek dengan cara memberikan reinforcement berupa token jika subjek berperilaku sesuai dengan harapan dan menghilangkan perhatian atau mengabaikan jika subjek memperlihatkan perilaku yang tidak diharapkan.

Penelitian ini bertujuan untuk mengungkap efektivitas modifikasi perilaku dengan teknik token ekonomi untuk menurunkan Conduct Disorders pada remaja putri di PSAA. Adapun hipotesis yang diajukan pada penelitian ini adalah ada penurunan perilaku Conduct Disorder antara sebelum dan sesudah mendapatkan modifikasi perilaku melalui teknik token ekonomi pada remaja putri di PSAA. 


\section{METODE PENELITIAN}

Subjek Penelitian. Penelitian ini menggunakan teknik purposeful sampling dalam pemilihan subjek, yaitu pemilihan sampel disesuaikan dengan tujuan penelitan (Patton, 2014). Prosedur penentuan sampel dalam penelitaian ini didasari oleh konstruk operasional (theory-based/operational construct sampling), di mana sampel dipilih dengan kriteria tertentu berdasarkan teori atau konstruk operasional sesuai dengan penelitian sebelumnya atau tujuan penelitian. Tujuan theory-based construct sampling adalah agar sampel benarbenar mewakili atau mempresentasikan fenomena yang dipelajari (Patton,2014). Dalam penelitian ini dipilih subjek yang memenuhi criteria remaja Conduct Disorders jenis antisocial dengan jenis kelamin perempuan dan memiliki masalah dengan perilaku.

Subjek dalam penelitian ini adalah seorang remaja perempuan yang memiliki Conduct disorder tipe antisosial berinisial PT yang berusia 16 tahun. Conduct disorder yang dimiliki PT termasuk jenis antisocial gangguan tingkah laku yang ditolak oleh teman sebaya. Penegakan Conduct disorder dilakukan oleh psikolog dengan mengacu kepada pedoman DSM IV (APA, 2020). Pengambilan data awal ini dilakukan dengan observasi dan wawancara kepada peksos, pramsos dan pengelola panti. Setelah itu, legalitas diagnosis dilakukan oleh seorang psikolog. PT memiliki tingkat kecerdasan di bawah rata-rata (IQ Kategori V SPM) dengan usia kematangan sosial 11 tahun 7 bulan (Skala VSMS). Adapun perilaku Conduct disorder PT berupa pemitingan dan perobekan baju pramsos, pemukulan kepada sesama anak penghuni panti, pencurian, dan berbohong kepada kepala panti.

Rancangan Penelitian. Penelitian ini berfokus pada perubahan tingkah laku dari seorang subjek sehingga desain yang digunakan adalah single-subject dengan tipe ABA Single-factor baseline (Abbott \& Bordens, 2011). Desain ABA Single-factor baseline dipilih karena penelitian ini bertujuan untuk melihat efektivitas sebuah variable bebas terhadap perubahan perilaku (variable terikat) dari tahap baseline (A) ke tahap intervensi (B). Perubahan dilihat dengan cara mengkondisikan subjek seperti pada tahap baseline (A) tanpa intervensi. Desain ABA sesuai untuk digunakan apabila memungkinkan untuk kembali kepada tahap sebelum intervensi setelah Intervensi selesai (Abbott \& Bordens, 2011). Variabel bebas dalam penelitian ini adalah intervensi modifikasi perilaku dengan teknik token ekonomi, sedangkan variabel tergantungnya adalah perilaku Conduct disorder.

Pengukuran. Ada beberapa metode pengambilan data dalam penelitian ini. Pertama: Diagnosis Conduct Disorder. Corcoran dan Walsh (2016) menyebutkan bahwa salah satu instrumen psikologis yang mampu mengungkap gangguan Conduct disorder adalah Children Behaviour Checklist (CBC) yang dikembangkan oleh Achenbach pada tahun 1991. CBC berbentuk checklist yang diisi oleh orang tua maupun wali terkait perilaku anak selama enam bulan terakhir. Diperuntukkan untuk anak usia usia empat sampai delapan belas tahun. Pengisian menggunakan skala likert dengan tiga pilihan jawaban, yakni 0 untuk tidak benar, 1 untuk jawaban kadang-kadang benar dan 2 untuk jawaban sangat benar/sering benar.

Checlist ini mampu mengungkap dua area primer anak, yakni kompetensi sosial sebanyak 20 item yang berisi mengenai intensitas dan kualitas partisipasi anak dalam beraktivitas, fungsi di sekolah, pekerjaan, pertemanan, dan sebagainya. Area lain yang mampu diungkap adalah masalah perilaku sebanyak 118 perilaku, terdiri atats delapan sindrom yang dibagi lagi menjadi tiga grup (internal, netral dan eksternal). Adapun grup internal terdiri atas sindrom yang mampu mengungkap kecemasan/depresi, somatic complain, dan withdrawl. Sedangkan group eksternal terdiri atas gejala yang mampu mengungkap Deliquent Behaviour, Aggressive Behaviour. Group netral terdiri atas Social Problems, Thought Problems, Attention Problems, dan Sex Problem. 
Pengukuran pada tahap penelitian dilakukan untuk mengukur perilaku conduct disorder. Pengukuran dilakukan pada tahap baseline sebelum perlakuan (A1). Pengukuran Conduct Disorders dilakukan dengan memberikan children behaviour checklist (CBCL) kepada pramsos yang dekat dengan subjek. Adapun hasil dari CBCL diperoleh bahwa subjek sering membantah, kejam terhadap binatang, kasar, suka mengolok-olok orang lain, merusak barang sendiri, merusak barang orang lain, berkelahi, impulsif, menyerang orang lain secara fisik, mencuri, mengancam dan lain sebagainya.

Kedua: Observasi. Dalam penelitian ini dilakukan observasi dengan menggunakan panduan observasi remaja Conduct disorder yang dirancang Ariati (Kurniawan, 2016). Observasi dilakukan saat baseline, perlakuan dan follow up.

Ketiga: Wawancara. Wawancara dilakukan dengan pramsos dan peksos untuk mengetahui perkembangan perilaku dan sejarah dari gangguan yang dialami oleh subjek. Wawancara dilakukan sebelum mendapat intervensi (baseline), pada masa intervensi dan setelah mendapatkan intervensi (follow-up). Adapun interview guide yang diberikan kepada pramsos dan peksos berdasarkan aspek Deliquent Behaviour, dan Aggressive Behaviour yang terungkap di hasil CBCL klien.

Prosedur. Berdasarkan rancangan intervensi, penelitian ini dilakukan dalam empat tahap sesuai dengan fase-fase modifikasi perilaku yang dikemukakan oleh Martin dan Pear (2019), yaitu intake, baseline, treatment dan follow up. Pertama: Intake. Tahap intake dilakukan untuk mengumpulkan informasi dengan tujuan mengidentifikasi masalah yang dimiliki PT dan tingkah laku yang akan menjadi target intervensi melalui waawancara, tes psikologi, dan observasi. Berdasarkan hasil pemeriksaan, PT memiliki tingkat kecerdasan umum di bawah rata-rata (skala SPM). Pengukuran kematangan sosial dilakukan dengan cara memberikan Vineland Social Maturity Scale (VSMS). Hasilnya menunjukkan bahwa PT memiliki tingkat kematangan sosial 11 tahun 7 bulan.

Kedua: Baseline. Tahap baseline dilakukan dengan memberikan prates untuk mengetahui tingkat Conduct Disorder yang dialami PT sebelum diberikan intervensi apapun. Pengukuran Conduct Disorders dilakukan dengan memberikan children behaviour checklist (CBCL) kepada pramsos yang dekat dengan PT. Adapun hasil dari CBCL diperoleh bahwa PT sering membantah, kejam terhadap binatang, kasar, suka mengolok-olok orang lain, merusak barang sendiri, merusak barang orang lain, berkelahi, impulsif, menyerang orang lain secara fisik, mencuri, mengancam dan sebagainya. Pada fase baseline juga dilakukan wawancara untuk menentukan token dan reinforce yang akan diberikan kepada PT selama intervensi.

Ketiga: Tahap treatment. Token economy 1 (perilaku agresif verbal, kata kotor, mesum). PT diberikan penjelasan singkat mengenai perilaku yang diperbolehkan dan perilaku yang dilarang. PT juga diberitahu bahwa perilakunya dicatat selama bermain. Pencatatan dilakukan selama lima jam dalam waktu sehari. Dalam waktu seminggu intervensi dilakukan selama tiga hari. Saat menunjukkan stimulus positif seperti meminta sesuatu dengan cara yang baik, sopan, dan manis, maka PT akan mendapatkan satu sticker bintang Merah Muda. Dalam waktu satu hari PT harus paham bahwa ia harus mengumpulkan 5 sticker bintang Merah Muda untuk mendapatkan satu lembar kertas mewarnai. Saat PT berhasil mengumpulkan 13-15 sticker bintang Merah Muda, maka PT akan mendapatkan ice cream pada akhir pekan.

PT juga dbuat memahami bahwa ia diberi peringatan jika ia menunjukkan stimulus negatif berupa kata kotor, mesum, kasar. PT diberikan peringatan pertama dengan respon kata-kata dan sentuhan yang masih positif. Jika stimulus tetap muncul, PT diberikan 
peringatan kedua dengan respon kata-kata positif namun tanpa sentuhan. Jika stimulus tetap muncul PT akan diberikan peringatan ketiga dengan respon netral. Jika stimulus tetap muncul maka PT mendapat sticker bintang Hitam dan diacuhkan (isolasi sosial).

Token economy 2 (perilaku agresif fisik, kasar, dan memukul). PT diberikan penjelasan singkat mengenai perilaku yang diperbolehkan dan perilaku yang dilarang. PT juga mengetahui bahwa perilakunya dicatat selama bermain. Pencatatan dilakukan selama lima jam dalam sehari. Dalam waktu seminggu intervensi dilakukan selama tiga hari. Jika PT menunjukkan stimulus positif seperti mampu bermain tanpa melibatkan kekerasan fisik maka PT akan mendapatkan satu sticker bintang Merah Muda. Dalam waktu satu hari PT harus paham bahwa ia harus mengumpulkan 5 sticker bintang Merah Muda untuk mendapatkan satu lembar kertas mewarnai. Jika PT berhasil mengumpulkan 13-15 sticker bintang Merah Muda maka PT akan mendapatkan ice cream pada akhir pekan.

PT juga harus memahami bahwa ia akan diberi peringatan jika ia menunjukkan stimulus negatif berupa kekerasan fisik maka PT akan diberikan peringatan pertama dengan respon kata-kata dan sentuhan yang masih positif. Jika stimulus tetap muncul, PT diberikan peringatan kedua dengan respon kata-kata positif namun tanpa sentuhan. Jika stimulus tetap muncul, PT diberikan peringatan ketiga dengan respon netral. Jika stimulus tetap muncul, PT mendapat sticker bintang Hitam dan diacuhkan (Isolasi sosial).

Keempat: Tahap follow up. Tahap follow-up terdiri atas pascates dan generalisasi. Pascates diberikan dan dicatat dengan cara yang sama dengan prates untuk melihat penurunan perilaku Conduct Disorder pada PT setelah intervensi. Generalisasi dilakukan seminggu setelah pemberian intervensi terakhir untuk melihat apakah penurunan perilaku yang ditunjukkan PT tetap bertahan setelah intervensi dihentikan. Generalisasi dilihat melalui metode observasi partisipatoris di mana peneliti mengamati perilaku PT dalam situasi seharihari.

Penelitian berlangsung selama 43 hari. Di Panti Sosial Asuhan Anak "X" tempat PT tinggal. Tempat ini dipilih agar PT bisa berproses di lingkungannya sendiri secara langsung. Adapun waktu pelaksanaan penelitian terangkum dalam tabel berikut.

Tabel 1. Waktu pelaksanaan penelitian

\begin{tabular}{|c|c|c|c|c|}
\hline No & Hari Ke- & Tahap Penelitian & Jam & Keterangan \\
\hline \multirow[t]{2}{*}{1} & I & $\begin{array}{l}\text { Pengukuran awal } \\
\text { (Base line) }\end{array}$ & $\begin{array}{c}30 \\
\text { Menit }\end{array}$ & $\begin{array}{l}\text { Bertujuan untuk mendapatkan data } \\
\text { pembanding sebelum subjek diberikan } \\
\text { intervensi apapun. Adapun alat yang } \\
\text { digunakan adalah CBCL }\end{array}$ \\
\hline & & $\begin{array}{l}\text { Penjelasan Token } \\
\text { Ekonomi } 1\end{array}$ & $\begin{array}{c}40 \\
\text { Menit }\end{array}$ & $\begin{array}{l}\text { Agar pelaksana memahami kondisi subjek } \\
\text { dan cara menangani tingkah laku agresif } \\
\text { verbal yang ditunjukkan subjek. } \\
\text { Token ekonomi berguna untuk menciptakan } \\
\text { suasana dan tingkah laku yang dikehendaki }\end{array}$ \\
\hline \multirow[t]{2}{*}{2} & 7 & $\begin{array}{l}\text { Pengukuran token } \\
\text { ekonomi minggu } \\
\text { pertama }\end{array}$ & $\begin{array}{c}30 \\
\text { Menit }\end{array}$ & $\begin{array}{l}\text { Dilakukan } 1 \text { minggu setelah token ekonomi } \\
\text { diberikan. Pengukuran dilakukan dengan } \\
\text { menggunakan CBCL }\end{array}$ \\
\hline & & $\begin{array}{l}\text { Evaluasi token } \\
\text { ekonomi minggu } \\
\text { pertama }\end{array}$ & $\begin{array}{c}40 \\
\text { Menit }\end{array}$ & $\begin{array}{l}\text { Untuk mengevaluasi perkembangan token } \\
\text { ekonomi minggu pertama }\end{array}$ \\
\hline 3 & 14 & $\begin{array}{l}\text { Pengukuran token } \\
\text { ekonomi minggu } \\
\text { kedua }\end{array}$ & $\begin{array}{c}30 \\
\text { menit }\end{array}$ & $\begin{array}{l}\text { Dilakukan } 1 \text { minggu setelah evaluasi token } \\
\text { ekonomi minggu pertama dilakukan. } \\
\text { Pengukuran dilakukan dengan menggunakan } \\
\text { CBCL }\end{array}$ \\
\hline
\end{tabular}




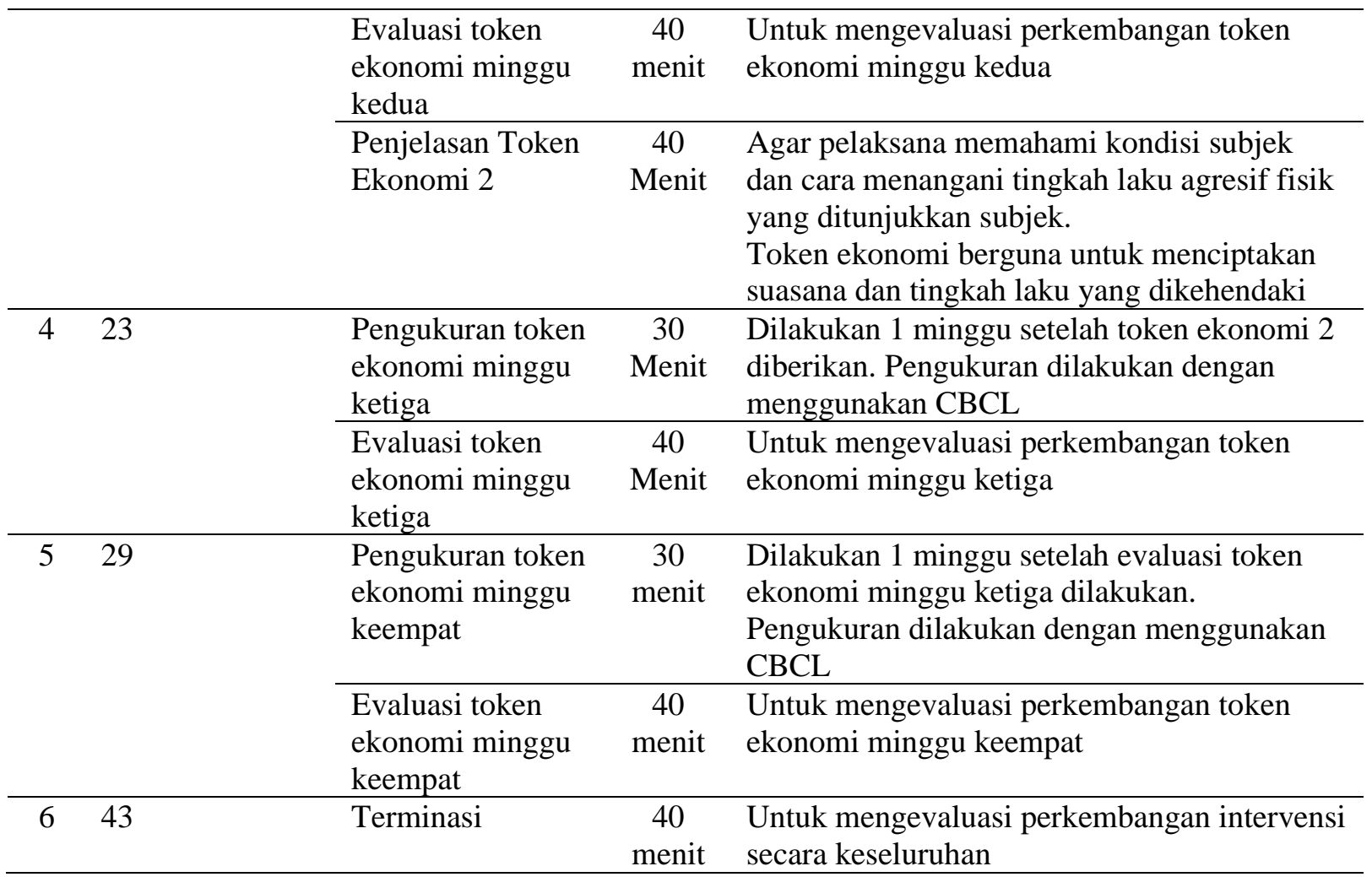

\section{HASIL PENELITIAN DAN PEMBAHASAN}

\section{Hasil Penelitian}

Hasil penelitian disajikan dalam bentuk gambar di bawah ini:
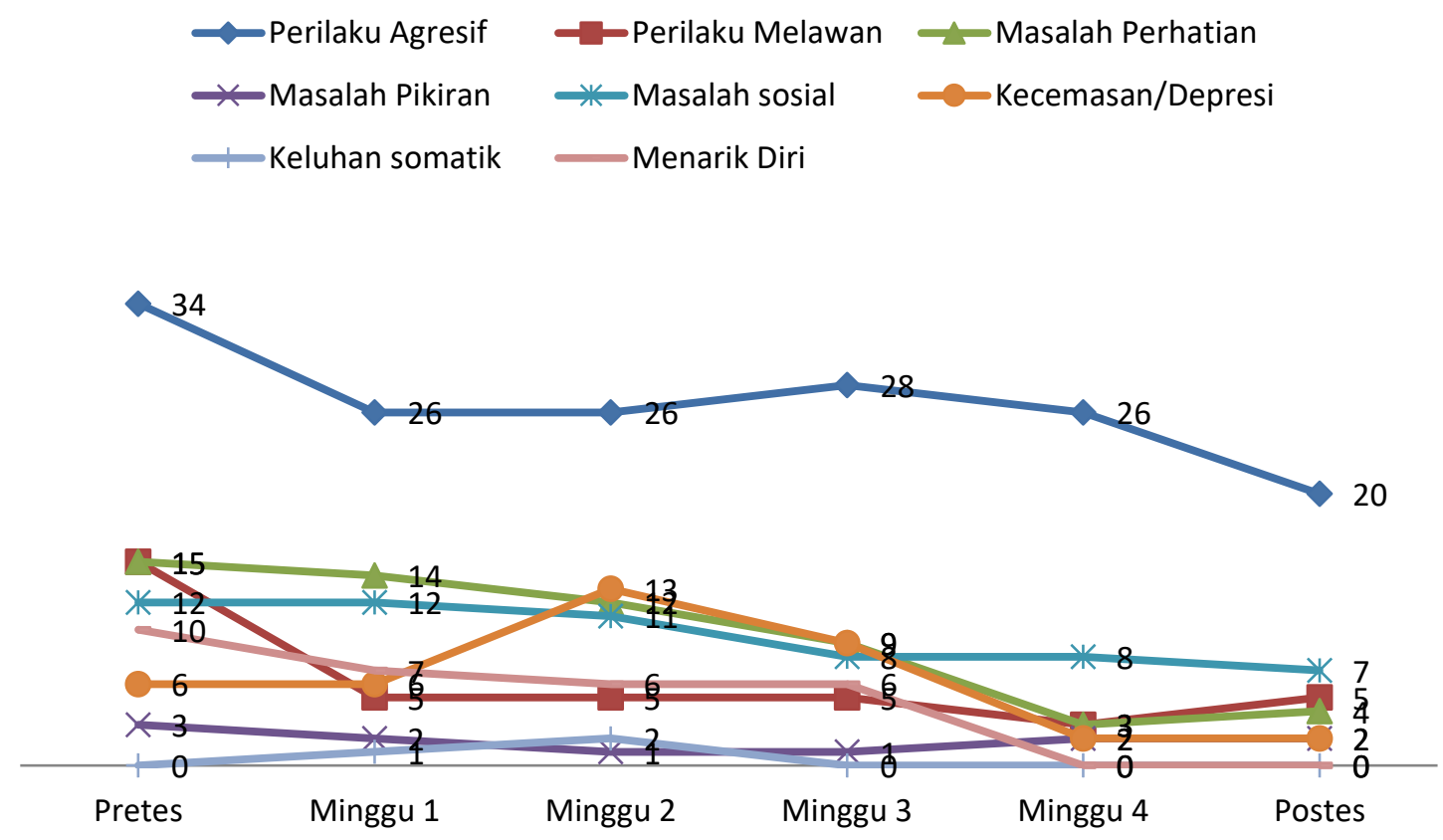

Dari grafik perilaku agresif, ditemukan penurunan pada perilaku agresif subjek. Pada pengukuran awal diperoleh skor CBCL sebesar 34. Hal ini mengindikasikan perilaku agresif subjek berada dalam kategori Clinical Range (Skor 21-39). Dibandingkan dengan skor pasca 
perlakuan ditemukan skor akhir sebesar 20 poin. Penurunan sebesar 14 poin tersebut mengubah kategori dari Clinical range menjadi Clinical Borderline (Skor 16-20) untuk aspek perilaku agresif.

Dari grafik perilaku melawan, ditemukan penurunan pada perilaku melawan. Pada pengukuran awal diperoleh skor CBCL sebesar 15. Hal ini mengindikasikan perilaku melawan subjek berada dalam kategori Clinical Range (Skor 8-25). Dibandingkan dengan skor pasca perlakuan ditemukan skor akhir sebesar 5 poin. Penurunan sebesar 10 poin tersebut mengubah kategori dari Clinical range menjadi Normal Range (Skor 0-5) untuk aspek perilaku melawan.

Dari grafik masalah perhatian, ditemukan penurunan pada masalah perhatian. Pada pengukuran awal diperoleh skor CBCL sebesar 15. Hal ini mengindikasikan masalah perhatian subjek berada dalam kategori Clinical Range (Skor 12-21). Dibandingkan dengan skor paska perlakuan ditemukan skor akhir sebesar 4 poin. Penurunan sebesar 11 poin tersebut mengubah kategori dari Clinical range menjadi Normal Range (Skor 0-8) untuk aspek masalah perhatian.

Dari grafik masalah pikiran, ditemukan penurunan pada masalah pikiran. Pada pengukuran awal diperoleh skor CBCL sebesar 3. Hal ini mengindikasikan masalah pikiran subjek berada dalam kategori Clinical Borderline (Skor 3-4). Dibandingkan dengan skor pasca perlakuan ditemukan skor akhir sebesar 2 poin. Penurunan sebesar 1 poin tersebut mengubah kategori dari Clinical range menjadi Normal Range (Skor 0-2) untuk aspek masalah pikiran.

Dari grafik masalah sosial, ditemukan penurunan pada masalah sosial. Pada pengukuran awal diperoleh skor CBCL sebesar 12. Hal ini mengindikasikan masalah sosial subjek berada dalam kategori Clinical Range (Skor 9-15). Dibandingkan dengan skor pasca perlakuan ditemukan skor akhir sebesar 1 poin. Penurunan sebesar 11 poin tersebut mengubah kategori dari Clinical range menjadi Normal Range (Skor 0-6) untuk aspek masalah sosial.

Dari grafik gangguan kecemasan/depresi, ditemukan penurunan pada gangguan kecemasan/depresi. Pada pengukuran awal diperoleh skor CBCL sebesar 6. Hal ini mengindikasikan gangguan kecemasan/depresi subjek berada dalam kategori Normal Range (Skor 0-11). Dibandingkan dengan skor pasca perlakuan ditemukan skor akhir sebesar 2 poin. Penurunan sebesar 4 poin tersebut mengindikasikan penurunan kecemasan/depresi pada subjek namun masih dalam kategorisasi Normal Range.

Dari grafik keluhan somatik, ditemukan penurunan pada keluhan somatik. Pada pengukuran awal diperoleh skor CBCL sebesar 0 point. Hal ini mengindikasikan keluhan somatik subjek berada dalam kategori Normal Range (Skor 0-5). Dibandingkan dengan skor pasca perlakuan tetap tidak terjadi perubahan dimana ditemukan skor akhir sebesar 0 poin. Tidak ditemukan perubahan skor awal dan akhir sehingga kategorisasi tidak berubah tetap menjadi Normal Range (Skor 0-5) untuk aspek keluhan somatik.

Dari grafik perilaku menarik diri, ditemukan penurunan pada perilaku menarik diri. Pada pengukuran awal diperoleh skor CBCL sebesar 10. Hal ini mengindikasikan perilaku menarik diri subjek berada dalam kategori Clinical Range (Skor 10-17). Dibandingkan dengan skor pasca perlakuan ditemukan skor akhir sebesar 0 poin. Penurunan sebesar 10 point tersebut mengubah kategori dari Clinical range menjadi Normal Range (Skor 0-7) untuk aspek perilaku menarik diri. 


\section{Pembahasan}

Dari hasil analisis data di atas maka diperoleh data bahwa secara keseluruhan teknik token ekonomi efektif menurunkan perilaku agresif secara fisik dan verbal pada remaja yang mengalami Conduct Disorder. Berdasarkan teori sebelumnya, remaja dengan Conduct Disorder memiliki berbagai karakteristik dan salah satunya adalah kesulitan untuk membedakan antara tingkah laku yang dapat diterima dan tingkah laku yang tidak dapat diterima. Jika remaja dengan gangguan ini mengetahui perbedaan keduanya, namun mereka gagal untuk mengembangkan kontrol terhadap tingkah lakunya (Santrock, 2018). Dengan melihat kondisi tersebut, maka diperlukan suatu intervensi untuk dapat menurunkan perilaku Conduct disorder dan dalam hal ini peneliti menggunakan teknik token ekonomi yang merupakan salah satu pendekatan behavioristik, dengan asumsi dari pendapat para ahli yang menyatakan bahwa "jika suatu tingkah laku diganjar maka probabilitas kemunculan kembali tingkah laku tersebut di masa mendatang akan meningkat" (Skinner, dalam Gordan, 2014).

Teknik token ekonomi adalah suatu cara untuk penguatan tingkah laku yang ditujukan kepada anak yang sesuai dengan target yang telah disepakati dengan menggunakan hadiah untuk penguatan yang simbolik (Barkley, 2015). Timothy dan Sran berpendapat, dalam token ekonomi tingkah laku yang diharapkan muncul bisa diperkuat dengan sesuatu yang diinginkan oleh anak, sehingga hasil perilaku yang diharapkan oleh kita bisa ditukar dengan sesuatu yang diinginkan oleh anak sehingga dengan adanya hadiah perilaku akan terus diulang (Brant, 2015). Token ekonomi merupakan salah satu contoh dari perkuatan ekstrinsik yang menjadikan seseorang melakukan sesuatu untuk meraihnya dengan tujuan untuk mengubah motivasi yang ekstrinsik menjadi motivasi yang instrinsik. Dengan cara ini diharapkan bahwa perolehan tingkah laku yang diinginkan dapat menjadi ganjaran untuk memelihara tingkah laku yang baru (Tarbox, dalam Belfiore \& Glascott, 2019). Hal ini sebagaimana pendapat Hapsari dan Hartiani (2018) yang menyatakan bahwa suatu jenis tingkah laku yang timbul dalam keadaan tertentu dapat diubah atau dimodifikasi. Dengan demikian jelaslah bahwa penurunan perilaku agresif fisik dan verbal pada remaja dengan Conduct Disorder dapat dimodifikasi dengan menggunakan teknik token ekonomi.

Anant dan Raguram (Parthasaraty \& Thirumoorthy, 2017) menjelaskan bahwa Conduct Disorder disebut sebagai suatu gangguan psikiatri yang serius karena merupakan kumpulan dari perilaku antisosial dan agresif yang menonjol pada awal anak-anak dan menetap sampai remaja, bahkan dewasa. Simtom-simtom antosisial sering sekali ditandai dengan perilaku menyakiti orang lain dan melakukan pelanggaran terhadap peraturan (Searight dkk, dalam Lillig, 2018). Simtom-simtom agresif yang muncul dapat berbentuk perbuatan menggertak, mengancam, menakut-nakuti, berkelahi, menggunakan senjata yang dapat membahayakan orang lain, kejam secara fisik terhadap orang lain, binatang, mencuri dan memaksa orang lain melakukan aktivitas seksual.

Dengan demikian, terdapat kesesuaian antar teori dan kondisi di lapangan bahwa token ekonomi dapat menurunkan perilaku agresif remaja dengan Conduct disorder. Secara keseluruhan, penerapan teknik token ekonomi berperan dalam menurunkan perilaku agresif fisik dan verbal pada remaja Conduct Disorders menghasilkan adanya peningkatan positif, meskipun hal tersebut masih cenderung naik turun atau tidak stabil dan belum mencapai tingkat yang maksimal.

Berdasarkan hasil analisis, pada intervensi pertama terjadi peningkatan perilaku positif. Hal ini terlihat dari meningkatnya jumlah perolehan token merah muda pada minggu pertama ke minggu kedua intervensi. Pada minggu pertama intervensi subjek memperoleh token merah muda sebanyak 12 token. Adapun peringatan pertama diperoleh subjek sebanyak 6 kali, dan peringatan kedua sebanyak 3 kali. Peningkatan perolehan token terjadi pada 
minggu kedua intervensi. Subjek memperoleh 15 token, peringatan pertama sebanyak 3 kali, dan peringatan kedua sebanyak 3 kali. Peningkatan jumlah token dipengaruhi oleh motivasi subjek. Subjek termotivasi untuk meningkatkan perolehan token dikarenakan ada keinginan subjek untuk bersekolah.

Pada intervensi kedua minggu pertama, subjek berhasil mendapatkan 8 token merah muda, 9 peringatan pertama, 2 peringatan kedua, 1 peringatan ketiga, dan 1 token hitam. Penurunan perolehan token pada subjek terjadi karena subjek harus dipindahkan ke wisma lain. Pemindahan subjek dikarenakan adanya penghuni wisma baru yang masih bayi. Kebijakan pemindahan dilakukan untuk mempermudah pramsos mengawasi anak bayi yang baru masuk ke Panti. Pemindahan subjek mengubah lingkungan dan kondisi pengawasan, di mana subjek harus beradaptasi dengan lingkungan wisma yang baru dan pramsos yang baru. Pada minggu kedua intervensi kedua terjadi penurunan perolehan token. Subjek berhasil mengumpulkan 6 token merah muda, 9 peringatan pertama, 6 peringatan kedua, 1 peringatan ketiga dan 3 token hitam.

\section{KESIMPULAN DAN SARAN}

Menjawab permasalahan dan tujuan, dapat disimpulkan bahwa pendekatan modifikasi perilaku dengan teknik token ekonomi efektif untuk menurunkan perilaku Conduct Disorder pada remaja putri di PSAA. Aspek yang paling besar menurunannya adalah Perilaku agresif (14 poin), masalah perhatian (11 poin), perilaku melawan (10 poin), perilaku menarik diri (10 poin), masalah sosial (5 poin), kecemasan/depresi (4 poin), masalah pikiran (1 poin), dan keluhan somatik (0 poin).

Untuk menyempurnakan penelitian yang dimiliki, maka peneliti mengajukan beberapa saran metodologis. Saran pertama adalah menambah referensi penelitian-penelitian mengenai perilaku subjek Conduct disorder dengan metode serupa untuk menentukan kriteria keberhasilan, spesifikasi waktu dan jumlah perilaku positif yang diajarkan sesuai dengan karakteristik subjek. Kedua, menambah jarak waktu antara intervensi dengan post test untuk melihat apakah perilaku yang dipelajari selama intervensi dapat bertahan dalam jangka panjang pada subjek. Ketiga, intervensi ini dapat diteliti secara ilmiah berkaitan berkaitan dengan sejauh mana efektivitasnya dalam menurunkan perilaku-perilaku negative dan destruktif individu.

Selain saran metodologis, peneliti turut mengajukan saran praktis untuk kesempurnaan penelitian. Adapun saran praktis pertama adalah keterlibatan Pramsos dan Peksos untuk memberikan reinforcement diluar intervensi adalah penting karena keberhasilan Intervensi berkaitan dengan daya ingat yang dapat diperkuat dengan adanya pengulangan. Reinforcement dapat dilakukan melalui hal-hal positif di luar intervensi yang dilakukan subjek sehari-hari dan sebagainya. Saran kedua mencari tahu minat subjek untuk menentukan token dan reinforcer dalam Intervensi. Hal ini penting karena setiap individu memiliki minat yang berbeda-beda. Saran ketiga, memberikan aktivitas-aktivitas tambahan yang menyenangkan bagi subjek untuk mempertahankan motivasi Intervensinya. Hal ini penting supaya intervensi tidak monoton dan membuat subjek bosan. Saran keempat, social reinforce penting diberikan untuk meningkatkan perasaan kompeten pada subjek dan mengurangi ketergantungan subjek pada hadiah dalam melaksanakan Intervensi. Reinforce ini dapat berupa pujian gestural maupun pendampingan dari Peksos/Pramsos dan orang terdekat yang menyaksikan keberhasilan subjek dalam melaksanakan Intervensi. Selain memasangkannya dengan social reinforce, pemberian token atau hadiah dapat dikurangi selama intervensi berlangsung. Saran kelima, mengajarkan significant others seperti Pramsos, Peksos, Guru secara sistematis mengenai cara pemberian intervensi berupa Intervensi dapat dilanjurkan dan 
subjek dapat berperilaku lebih positif. Saran keenam, intervensi dapat dikembangkan untuk menurunkan atau meningkatkan hal-hal lain yang berkaitan dengan perilaku subjek. Saran terakhir, jika sudah ada koordinasi antara pihak panti dengan pihak sekolah, Intervensi ini bisa dilaksanakan disekolah. Hal ini dilakukan supaya subjek dapat mempertahankan perilaku positif tidak hanya dipanti namun disetiap lingkungan tempatnya berada.

\section{DAFTAR PUSTAKA}

Abbott, B. B., \& Bordens, K. S. (2011). Research design and methods: A process approach. $8^{\text {th }}$ edition. New York, NY 10020: McGraw-Hill Companies, Inc

American Psychiatric Assosiation. (2020). Dignostic and Statistical Manual of Mental Disorders. $5^{\text {th }}$ edition-Text Revision. Washington DC: American Psychiatric Assosiation.

Barkley, R., A. (2015). Attention Deficit Hyperactivity Disorder: A Handbook for Diagnosis and Tretment. $4^{\text {th }}$ Edition. The Guilford Press

Belfiore, P, J and Glascott, T. (2019). The Effects of Token Reinforcement, in The Form of A Lottery, on Noncompliance in a Urban Third Grade Classroom. Psychology and Behavioural Sciece International Journal, Vol. 13, Issue. 5. 1-7

Brant, J, A., Dozier, C, L., Juanico, J, F., Laundony, C, L., Mick, B, R. (2015). The Value of Choice as a Reinforcer For Typically Developing Children. Journal of Applied Behavior Analysis. 48, 344-362.

Corcoran, J. \& Walsh, J. (2016). Clinical Assessment and Diagnosis in Social Work Practice. $3^{\text {th }}$ edition. NY: Oxford University Press.

Corey, G. (2016). Student Manual for Theory and Practice of Counseling and Psychotherapy. $10^{\text {th }}$ Edition. USA: Brooks/Cole

Davison, G.C., Neale, J.M., \& Kring, A.M. (2018). Psikologi Abnormal. Edisi ke-9. Penterjemah: Noermalasari Fajar. Jakarta: Rajawali P

Fairchild, G., Hawes, D, J., Frick, P., Copeland, W., Odgers, C, L., Franke, B., Freitag, C, M., Brito, S. (2019). Conduct Disorders. Nature Review, Vol. 5, No. 43, 1-25

Frick, P, J. (2016). Current Research on Conduct Disorders in Children and Adolescents. South Africa Jurnal of Psychology, Vol. 46, No. 2, 160-174.

Gordan, M. (2014). A Review of B.F Skinners Reinforcement Theory of Motivation. International Journal of Research in Education Methodology. Vol. 5, No. 3, 680-688

Hapsari, C, K., Hartiani, F. (2018). Penerapan Prinsip Modifikasi Perilaku Untuk Maningkatkan Kemampuan Menyikat Gigi Pada Anak Dengan Diabilitas Intelektual Berat. Jurnal Psikologi, Vol. 17, No. 2, 119-130

Katona, C., Cooper, C., \& Robertson, M. (2012). At a Glance Psychiatry. Edisi ke-4. Jakarta: Erlangga

Kurniawan, W. (2016). Pengaruh Terapi Kognitif Perilakuan Untuk Menurunkan Gangguan Perilaku Menantang Pada Siswa MTS X di Yogyakarta. Jurnal Society, Vol. 6, No. 2, 49-73

Lillig., M. (2018). Conduct Disorder: Recognition and Management. American Family Physician, Vol. 98, Number 10, 584-592 
Maslihah, S. (2013). Play Therapy Dalam Identifikasi Kasus Kekerasan Seksual Terhadap Anak. Jurnal Penelitian Psikologi, Vol.04, No 01, 21-34

Mash, E, J., \& Wolfe, D, A. (2013). Abnormal Child Psychology. USA: Wadhsworth.

Martin, G \& Pear, J. (2019). Behaviour Modification: What It Is and How To Do It. $11^{\text {th }}$ Edition. NY: Routledge

Noviana, I. (2015). Kekerasan Seksual Terhadap Anak: Dampak dan Penanganannya. Jakarta: Pusat Penelitian dan Pengembangan Kesejahteraan Sosial, Kementrian Sosial Republik Indonesia

Patton, M. Q. (2014). Qualitative Evaluation and Research Methods ( $5^{\text {rd }}$ edition). California: Sage Publication, Inc

Parthasarathy, R \& Thirumoorthy, T, R. (2017). Culturally Relevant Family Therapy Practice with Parents of Children and Adolescents. Indian Journal of Psychological Medicine, Vol. 29. No. $2,137-142$

Pisano, S., Muratori, P., Gorga, C., Levantini, V., Luliano, R., Catone, G., Copola, G., Milone, A dan Masi., G. (2017). Conduct Disorders and Psucophathy in Children And Adolescents: Aetiology, Clinical Presentation and Treatment Strategies of Callous-Unemotional Traits. Italian Journal of Pediatrics, Vol. 43, No. 84, 1-11

Podgurski, I., Lyons, J. S., Kisiel, C., Griffin, G. (2014). Understanding Bad Girls: The role of trauma in antisocial behavior among female youth. Residential Treatment for Children and Youth, 33, $80-88$

Rider, G, N., Berg, D., Pardo, S, T., Kennedy, J, O., Sharp, K., Tran., K, M., Calvetti, S., Meier, C, L, K. (2019). Using The Child Behaviour Checklist (CBCL) With Transgender/Gender Nonconforming Children and Adolescents. Clinical Practice In Pediatric Psychology, Vol. 7, No. 3, 291-301

Santrock, J.W. (2018). Adolescence. $11^{\text {th }}$ Edition. NY: McGrew-Hill,Inc

Santrock, J.W. (2019). Life Span Development. $17^{\text {th }}$ Edition. NY: McGraw-Hill, Inc

Scott, S. (2012). An update on Intervention for Conduct disorders. Advance in Psychiatric Treatment, $14,61-70$

United Nations Childrens Fund. (2020). Situasi Anak di Indonesia - Tren, Peluang, dan Tantangan Dalam Memenuhi Hak-hak Anak. Jakarta: UNICEF Indonesia

Waddell, C., Schwartz, C., Andres, C., Barican, J, L., Yung, D. (2018). Fifty Years Preventing and Treating Childhood Behaviour Disorders: A Systematic Review to Inform Policy and Practice. Evid Based Mental Health. Vol 21, No. 2, 45-52

www.kpai.go.id. Undang-undang Republik Indonesia Nomor 35 Thaun 2014 Tentang Perubahan Atas Undang-Undang Nomor 23 Tahun 2002 Tentang Perlindungan Anak. Artikel tanggal 1 November 2014. Diunduh tanggal 10 Februari 2021

www.merdeka.com. Koma Dua Pekan, Remaja Perempuan Korban pelecehan Seksual dan Kekerasan Meninggal. Artikel tanggal 12 Februari 2020. Diunduh tanggal 1 Februari 2021

www.nasional.kompas.com. Kementrian PPPA: Sejak Januari Hingga Juli 2020 ada 2.556 Anak Korban Kekerasan Seksual. Artikel tanggal 24 Agustus 2020. Diunduh tanggal 1 Februari 2021 